\title{
PENERAPAN AUGMENTED REALITY PADA APLIKASI "PANDUKAWAN" (PENGENALAN WAYANG PANDAWA DAN PUNAKAWAN)
}

\author{
Muhamad Nurkhafid $^{1 *}$, Mustagfirin ${ }^{2}$ \\ ${ }^{1,2}$ Jurusan TEKNIK INFORMATIKA , Fakultas TEKNIK, Universitas Wahid Hasyim \\ Jl. Menoreh Tengah X/22, Sampangan, Semarang 50236. \\ "Email: muhamadnurkhafid@gmail.com
}

\begin{abstract}
Abstrak
Cinta Tanah Air bisa diwujudkan dengan mengenal dan mempelajari seni budaya Indonesia misalkan Pewayangan. Dari hal tersebut mengingatkan penulis pada Perkumpulan Seni Budaya dan Gedung Cagar Budaya "Sobokarti" Kota Semarang untuk belajar mengenal Pewayangan, namun sayangnya media belajar di tempat tersebut masih sangat manual dan belum menggunakan peralatan teknologi yang memadai, kalaupun ada itu dari inisiatif peserta didik misalkan merekam suara dari seorang guru ketika sedang menerangkan. Dengan demikian perlu diterapkan media baru untuk mempermudah peserta didik dan masyarakat dalam belajar wayang. Dari kasus tersebut mendorong penulis untuk melakukan penelitian dengan membuat aplikasi. Pada proses pembuatan aplikasi penulis menggunakan metode Waterfall sebagai metode pengembangan perangkat lunak. Metode tersebut meliputi tahap Analisis, Desain, Implementasi, Verifikasi dan Maintenance. Aplikasi nantinya berjalan pada smartphone. Pembangunan aplikasi menggunakan Unity 3D dengan pemanfaatan Augmented Reality Vuforia SDK. Kemudian untuk pembuatan objek 3D menggunakan software 3Ds Max. Sedangkan pemodelanya aplikasi ini menggunakan metode UML berupa use case diagram, activity diagram, dan sequence diagram. Pada akhirnya hasil dari penelitian ini adalah dihasilkan sebuah aplikasi android yang diberi nama aplikasi ” PANDUKAWAN " yang merupakan singkatan dari Pengenalan Pandawa dan Punakawan. Aplikasi tersebut kemudian diuji dengan metode pengujian blackbox dan mobile device.
\end{abstract}

Kata kunci: PHP Augmented Reality, Unity 3D, Vuforia SDK, Wayang, 3Ds Max

\section{PENDAHULUAN}

Salah satu nilai pendidikan budaya dan karakter kebangsaan yaitu Cinta Tanah Air Cinta Tanah Air sediri bisa diwujudkan dengan mengenal dan mempelajari seni budaya misalkan Pewayangan.

Menurut penuturan dari FX. Roejito selaku dalang sekaligus pengajar pedalangan di Perkumpulan Seni Budaya dan Gedung Cagar Budaya "Sobokartti" Kota Semarang, mengutarakan dunia pewayangan ini tidak akan punah jika para generasi penerus bangsa ini sadar akan pentingnya menjaga dan melestarikan seni budaya khususnya pewayangan sebagai salah satu identitas bangsa.

Media belajar pewayangan di Perkumpulan Seni Budaya dan Gedung Cagar Budaya "Sobokartti" Kota Semarang masih sangat manual, belum menggunakan peralatan teknologi yang memadai, kalaupun ada itu dari inisiatif peserta didik misalkan merekam suara dari seorang guru ketika sedang menerangkan. Dengan kondisi demikian penulis menemukan sebuah ide untuk membuat suatu aplikasi Augmented Reality sederhana bernama
"PANDUKAWAN" singkatan dari Pengenalan Wayang Pandawa dan Punakawan. Aplikasi tersebut akan memperkenalkan tokoh Pandawa dan tokoh Punakawan secara 3D beserta informasinya kepada anak-anak didik baru serta masyarakat yang akan belajar mendalang. Dengan demikian penulis berharap media belajar berbasis Augmented Reality yang digunakan akan semakin diminati dan mudah.

Augmented reality mengkombinasikan dunia nyata dengan komputer grafis, menyediakan interaksi dengan objek maya pada waktu nyata, dapat membawa objek maya pada dunia nyata, mengenali gambar atau objek, dan menyediakan konteks/data dengan waktu nyata dengan menambahkan nilai dengan informasi virtual. Visualisasi objek dunia maya pada dunia nyata memungkinkan dapat menutup objek dunia nyata atau pula mengubah perspektif dunia nyata itu sendiri. Misalnya augmented reality dapat menutup meja dengan sebuah gajah besar.

Rumusan masalah dalam penelitian ini yaitu bagaimana hasil penerapan Augmented Reality pada Aplikasi "Pandukawan" (Pengenalan Wayang Pandawa dan Punakawan) 
sebagai media belajar untuk mempermudah peserta didik dan masyarakat sekitar Perkumpulan Seni Budaya dan Gedung Cagar Budaya "Sobokartti" dalam mengenal tokoh Pandawa dan Punakawan.

Adapun batasan masalah pada penelitian ini yaitu aplikasi hanya membahas tentang Pengenalan Tokoh Wayang Pandawa dan Punakawan Berbasis Augmented Reality, aplikasi akan dilakukan pengujian dengan pengujian Black Box dan Mobile Device, aplikasi hasil rancangan dikembangkan ke Android, dan image marker berupa buku tokoh wayang Pandawa dan Punakawan.

Tujuan penelitian ini yaitu mengetahui bagaimana hasil penerapan Augmented Reality pada aplikasi "Pandukawan" (Pengenalan Wayang Pandawa dan Punakawan) sebagai media belajar untuk mempermudah peserta didik dan masyarakat sekitar Perkumpulan Seni Budaya dan Gedung Cagar Budaya "Sobokartti" agar bisa belajar dimana saja tanpa bertemu secara langsung dengan guru pedalangan.

\section{LANDASAN TEORI}

\subsection{Nilai Pendidikan Budaya dan Karakter Bangsa}

Perlu kita ketahui bahwa nilai-nilai yang dikembangkan dalam pendidikan budaya dan karakter bangsa diidentifikasi dari sumbersumber diantaranya: Agama, Pancasila , Budaya dan Tujuan Pendidikan Nasinal. Sedangkan nilai-nilai yang dikembangkan dalam pendidikan budaya dan karakter bangsa adalah sebagai berikut: Religius ,Jujur,Toleransi , Disiplin, Kerja Keras, Kreatif, Mandiri, Demokratis, Rasa Ingin Tahu, Semangat Kebangsaan, Cinta Tanah Air, Menghargai Prestasi, Bersahabat, Cinta Damai, Gemar Membaca, Peduli Lingkungan, Peduli Sosial, Tanggung-jawab.

\subsection{Sekilas Wayang Pandawa dan Punakawan}

Secara umum, pengertian wayang adalah suatu bentuk pertunjukan tradisional yang disajikan oleh seorang dalang, dengan menggunakan boneka atau sejenisnya sebagai alat pertunjukan (Tim Presentasi, 2008:2).

Pandawa terdiri dari lima orang pangeran, tiga di antaranya (Yudistira, Bima, dan Arjuna) merupakan putra kandung Kunti, sedangkan yang lainnya (Nakula dan Sadewa) merupakan putra kandung Madri, namun ayah mereka sama, yaitu Pandu.

Punakawan terdiri atas 4 bersaudara diantaranya Semar, Gareng, Petruk kemudian Bagong.

\subsection{Augmented Reality}

Menurut Carmigniani dan Furht (2011) ide AR sebenarnya telah muncul sekitar tahun 1950an ketika Morton Heilig memikirkan tentang pengalaman menonton yang dapat menarik penontonnya agar dapat berinteraksi dengan menarik semua indera penonton. Namun beberapa tahun belakangan AR berkembang lebih jauh karena mulai berkembangnya mobile device yang mendukung penggunaan AR.

Pada dasarnya, Augmented Reality mengkombinasikan dunia nyata dengan komputer grafis, menyediakan interaksi dengan objek maya pada waktu nyata, dapat membawa objek maya pada dunia nyata, mengenali gambar atau objek, dan menyediakan konteks/data dengan waktu nyata dengan menambahkan nilai dengan informasi virtual. Visualisasi objek dunia maya pada dunia nyata memungkinkan dapat menutup objek dunia nyata atau pula mengubah perspektif dunia nyata itu sendiri. Misalnya augmented reality dapat menutup meja dengan sebuah gajah besar.

Pada tahun 1997 Ronald Azuma mendefinisikan augmented reality sebagai sistem yang memiliki karakter sebagai berikut:

a. Menggabungkan lingkungan nyata dan virtual;

b. Berjalan secara interaktif dalam waktu nyata;

c. Integrasi dalam tiga dimensi (3D)

\section{METODE PENGEMBANGAN SISTEM}

Dalam perancangan aplikasi ini, penulis mengimplementasikan metode Waterfall atau sering disebut dengan classic life cycle (Pressman, 2010) sebagai metode pengembangan perangkat lunak yang meliputi tahap

1. Analisis

2. Desain

3. Implementasi

4. Verifikasi

5. Maintenance

Pemodelan sistem dilakukan dengan menggunakan metode UML yang meliputi use 
case diagram, activity diagram dan sequence diagram.

\subsection{Flowchart Perancangan Aplikasi}

Flowchart perancangan aplikasi merupakan suatu alur secara keseluruhan tentang pembuatan aplikasi. Maka dari itu persiapan yang dilakukan mulai dari mencari informasi mengenai Gedung Cagar Budaya Sobokartti, menentukan tokoh wayang yang akan dijadikan objek 3D, mendesain buku marker dan mengintegrasikan ke library Vuforia. Flowchart untuk perancangan aplikasi ini dapat dilihat pada Gambar 1.

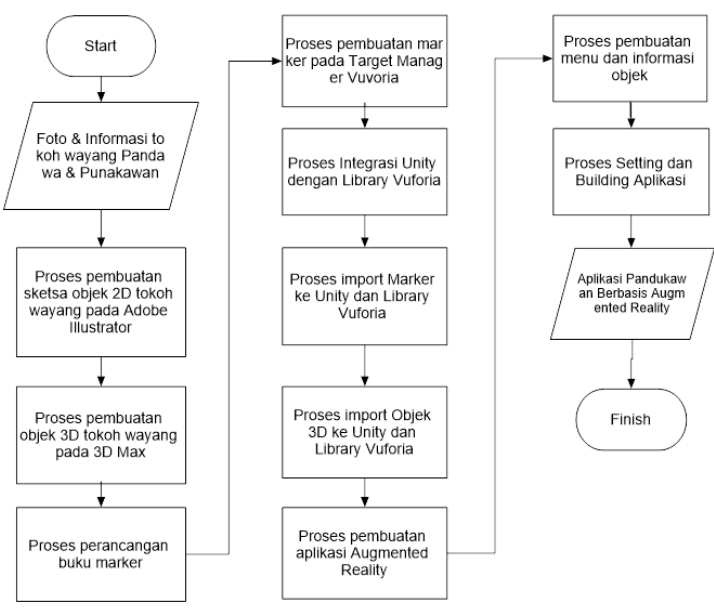

Gambar 1. Flowchart Perancangan Aplikasi

\subsection{Use Case Diagram}

Use Case Diagram digunakan untuk mengetahui fungsi apa saja yang ada didalam sebuah sistem dan siapa saja yang berhak menggunakan fungsi-fungsi tersebut. Yang ditekankan pada diagram ini adalah "apa" yang diperbuat sistem, dan bukan "bagaimana". Use Case Diagram mendeskripsikan interaksi antara satu atau lebih aktor dengan sistem yang akan dibuat, seperti yang ditunjukkan pada Gambar 2.

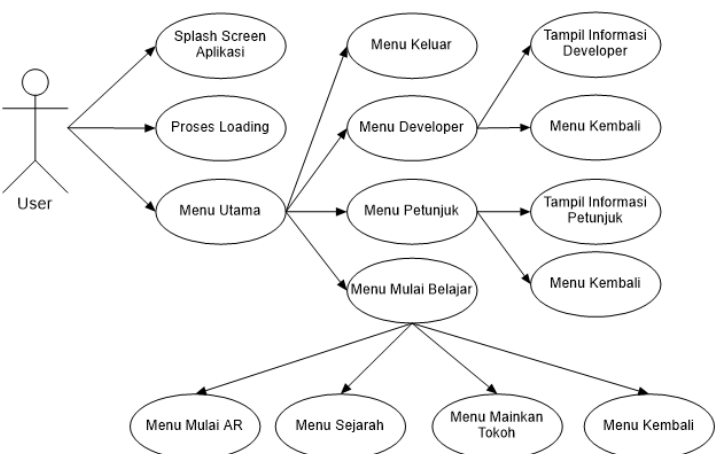

Gambar 2. Use case Aplikasi

\subsection{Diagram Activity}

Activity Diagram penggunaan aplikasi menggambarkan alur aktivitas yang terjadi dalam aplikasi Augmented Reality "PANDUKAWAN". Activity Diagram Menu aplikasi Augmented Reality menjelaskan saat user menggunakan menu-menu utama yang terdapat pada aplikasi ini. Activity Diagram pada menu khusus aplikasi dalam menampilkan objek AR ditunjukkan pada Gambar 3.

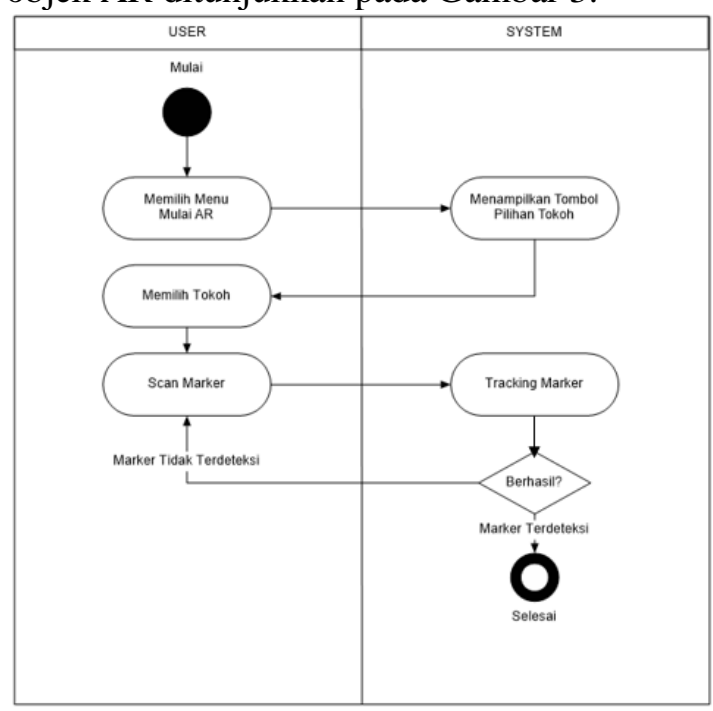

Gambar 3. Activity Diagram AR Pandukawan

Pada Gambar 3. ketika user memilih tombol Menu Mulai AR, sistem menampilkan pilihan tokoh kemudian user memilih salah satu tokoh, sistem akan menghidupkan kamera, kemudian user menunjukkan marker pada kamera untuk dideteksi/scan, kemudian sistem melakukan tracking marker. Jika marker tidak ada maka akan kembali ke proses menunjukkan marker oleh user, jika terdeteksi maka akan diteruskan ke proses selanjutnya.

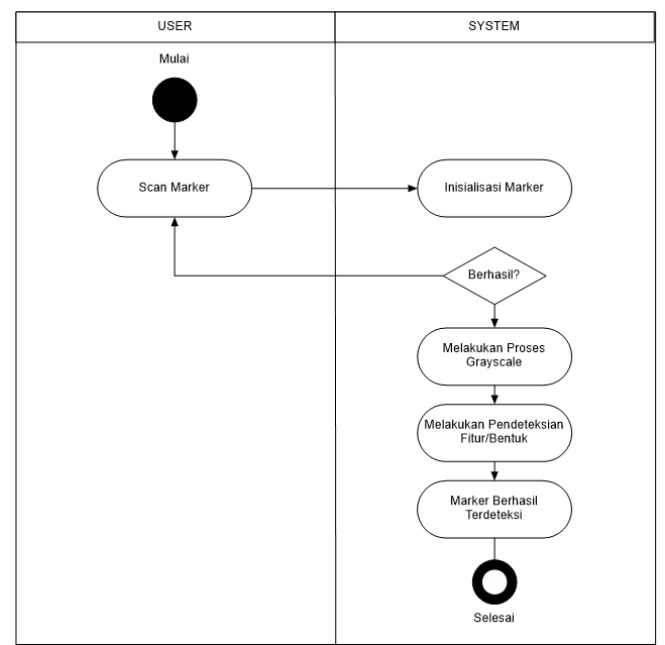

Gambar 4. Activity Diagram AR Pandukawan 
Pada Gambar 4. ketika user menunjukkan marker untuk dideteksi/scan, sistem melakukan inisialisasi pada marker. Jika marker terinisialisasi maka sistem melakukan pendeteksian fitur dan marker berhasil terdeteksi.

\subsection{Sequence Diagram}

\section{Penggunaan Sequence Diagram pada aplikasi Augmented Reality} "PANDUKAWAN" menggambarkan perilaku user terhadap sistem untuk menampilkan suatu objek, seperti yang ditunjukkan pada Gambar 5.

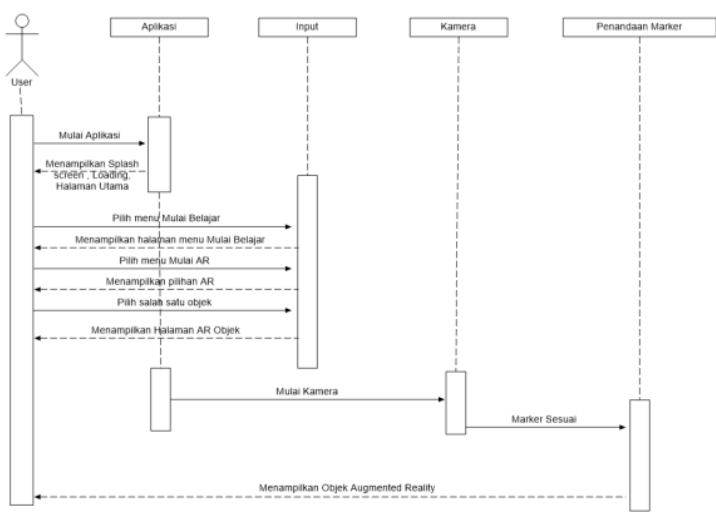

Gambar 5. Sequence Diagram dalam Proses Menampilkan Objek 3D

\section{HASIL DAN PEMBAHASAN}

\section{1 Marker}

Vuforia menggunakan algoritma FAST Corner Detection untuk mendefinisikan seberapa baik gambar dapat dideteksi dan dilacak menggunakan Vuforia SDK. FAST Corner Detection yaitu pendeteksian dengan mencari titik-titik (insert point) atau sudut (corner) pada suatu gambar, seperti yang ditunjukkan pada Gambar 6.
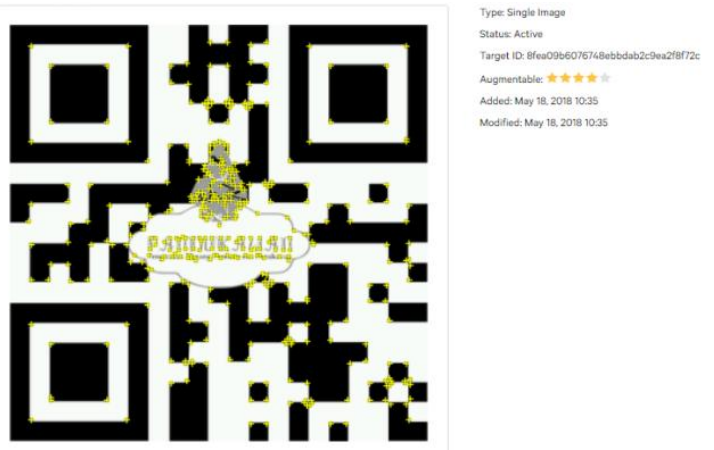

Gambar 6. Pendeteksian Marker dengan Insert Point

\subsection{Hasil}

a. Tampilan Halaman Splash Screen

Halaman Splash Screen dan Loading untuk mengawali aplikasi Pandukawan, seperti yang ditunjukkan pada Gambar 7.
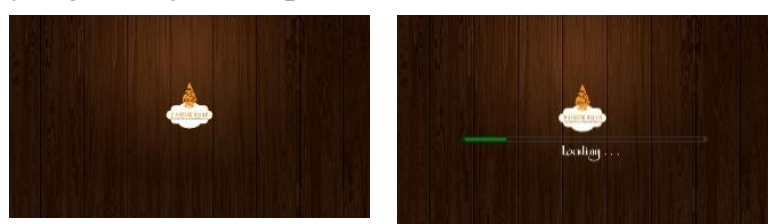

Gambar 7. Halaman Splash Screen dan Loading Aplikasi

\section{b. Tampilan Halaman Menu Utama}

Halaman menu utama sebagai halaman pilihan menu kepada User, seperti yang ditunjukkan pada Gambar 8.

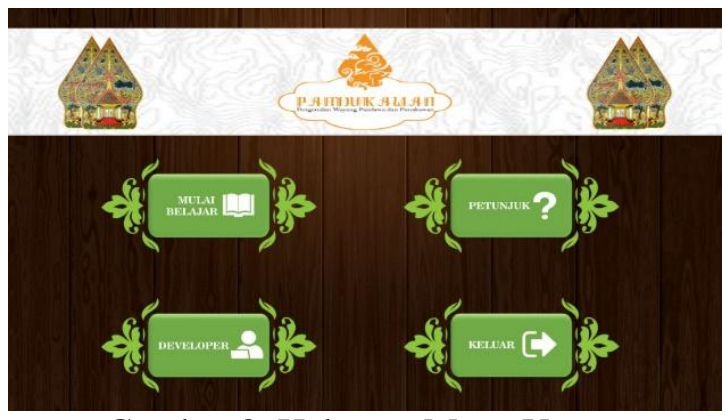

Gambar 8. Halaman Menu Utama

\section{c. Tampilan Halaman Mulai Belajar}

Halaman ini menunjukkan halaman Mulai Belajar yang terdiri atas tiga submenu diantaranya Mulai AR, Sejarah, dan Mainkan Tokoh, seperti yang ditunjukkan pada Gambar 9.

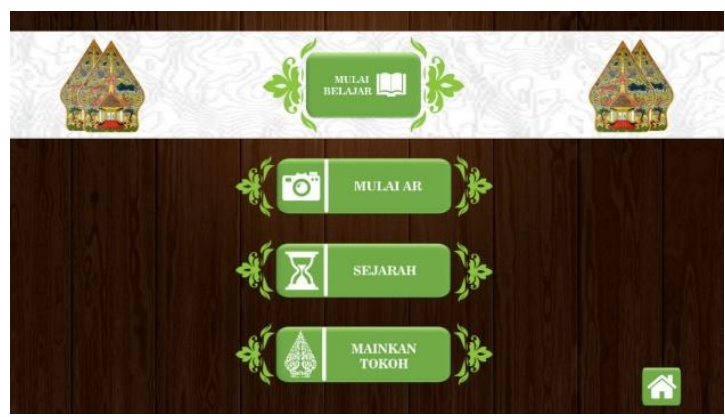

Gambar 9. Halaman Mulai Belajar

\section{d. Tampilan Halaman Mulai AR}

Halaman ini digunakan untuk memulai proses Augmented Reality, seperti yang ditunjukkan pada Gambar 10. 


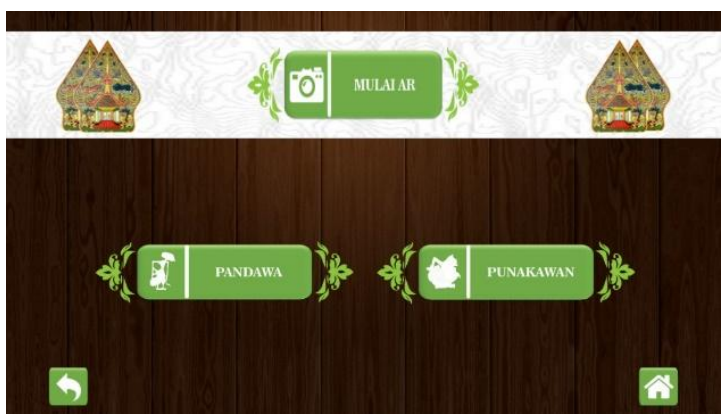

Gambar 10. Halaman Mulai AR

\section{e. Halaman Pilihan AR Pandawa}

Halaman ini digunakan untuk memilih tokoh wayang Pandawa manakah yang ingin ditampilkan informasinya, seperti yang ditunjukkan pada Gambar 11.

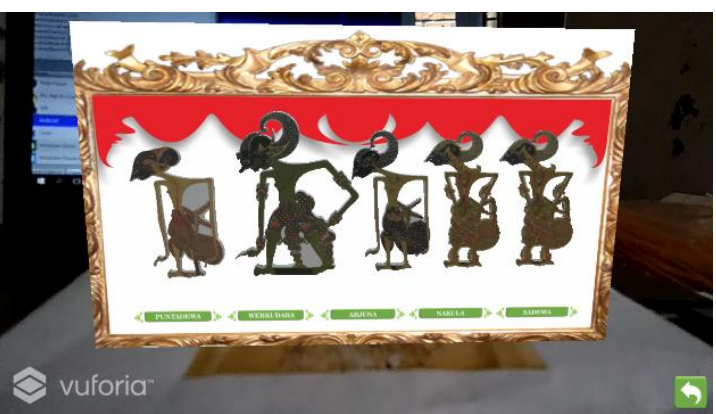

Gambar 11. Halaman Pilihan AR Pandawa

\section{f. Tampilan Halaman Sejarah}

Halaman ini digunakan untuk menampilkan sejarah dari Pandawa, seperti yang ditunjukkan pada Gambar 12.

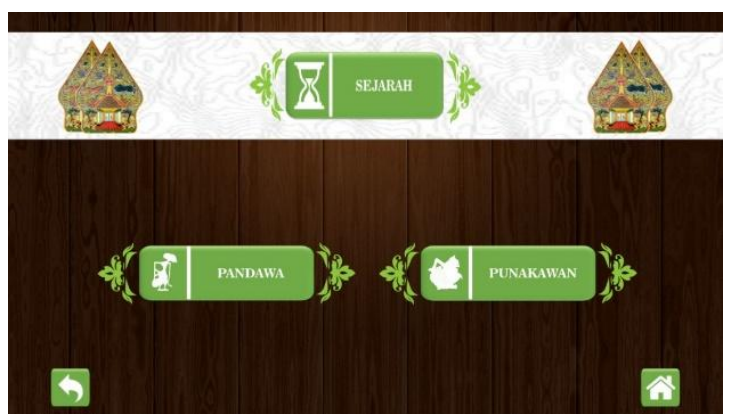

Gambar 12. Halaman Sejarah

g. Tampilan Sejarah Pandawa

Halaman ini menampilkan sejarah Pandawa, seperti yang ditunjukkan pada Gambar 13.

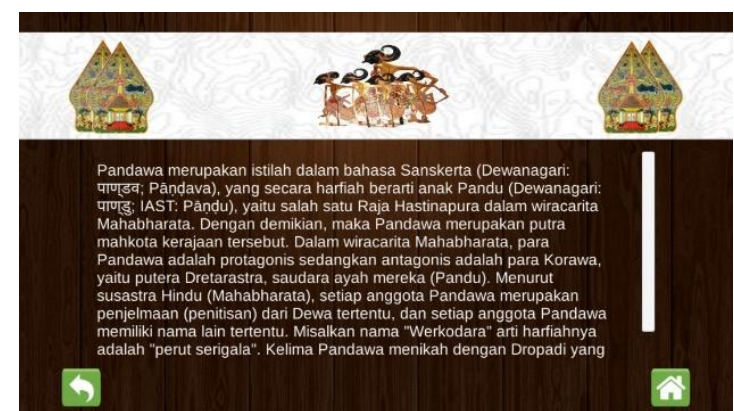

Gambar 13. Halaman Sejarah Pandawa

\section{h. Tampilan Halaman Mainkan Tokoh}

Halaman ini digunakan untuk memainkan tokoh wayang, seperti yang ditunjukkan pada Gambar 14.
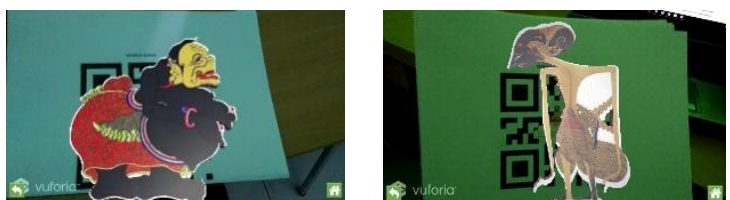

Gambar 14. Halaman Mainkan Tokoh

i. Tampilan Halaman Petunjuk

Halaman ini digunakan menampilkan petunjuk penggunaan aplikasi ini, seperti yang ditunjukkan pada Gambar 15.

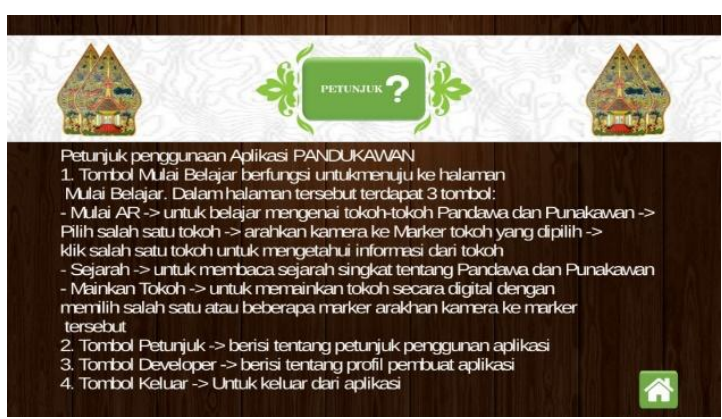

Gambar 15. Halaman Petunjuk

\section{j. Tampilan Halaman Developer}

Halaman ini digunakan untuk menampilkan developer aplikasi ini, seperti yang ditunjukkan pada Gambar 16.

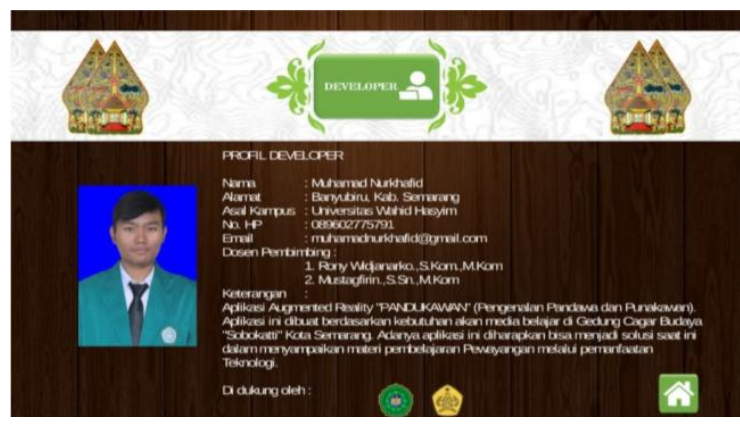

Gambar 16. Halaman Developer 


\subsection{Pengujian Sistem}

\subsubsection{Pengujian Black Box}

Pengujian black box merupakan pengujian aspek fundamental sistem tanpa memperhatikan struktur logika internal perangkat lunak. Metode ini untuk mengetahui apakah perangkat lunak berfungsi dengan benar.

Pengujian black box merupakan metode perancangan data uji yang didasarkan pada spesifikasi perangkat lunak. Data uji dieksekusi pada perangkat lunak di cek apakah sudah sesuai dengan yang di harapkan.

Untuk hasil pengujian Black Box bisa dilihat pada Tabel 1.

Tabel 1. Hasil Pengujian Black Box

\begin{tabular}{|c|c|c|c|}
\hline No & Tombol & Fungsi & Hasil \\
\hline \multicolumn{4}{|c|}{ Halaman Menu Utama } \\
\hline 1 & $\begin{array}{l}\text { Mulai } \\
\text { Belajar }\end{array}$ & $\begin{array}{l}\text { Menuju ke halaman } \\
\text { Mulai Belajar }\end{array}$ & Berhasil \\
\hline 2 & Petunjuk & $\begin{array}{l}\text { Menuju ke halaman } \\
\text { Petunjuk }\end{array}$ & Berhasil \\
\hline 3 & Developer & $\begin{array}{l}\text { Menuju ke halaman } \\
\text { Developer }\end{array}$ & Berhasil \\
\hline 4 & Keluar & $\begin{array}{l}\text { Untuk keluar dari } \\
\text { aplikasi } \\
\text { "PANDUKAWAN" }\end{array}$ & Berhasil \\
\hline \multicolumn{4}{|c|}{ Halaman Menu Mulai Belajar } \\
\hline 1 & Mulai AR & $\begin{array}{l}\text { Menuju ke halaman } \\
\text { Mulai AR }\end{array}$ & Berhasil \\
\hline 2 & Sejarah & $\begin{array}{l}\text { Menuju ke halaman } \\
\text { Sejarah }\end{array}$ & Berhasil \\
\hline 3 & $\begin{array}{l}\text { Mainkan } \\
\text { Tokoh }\end{array}$ & $\begin{array}{l}\text { Menuju halaman deteksi } \\
\text { marker }\end{array}$ & Berhasil \\
\hline 4 & Home & $\begin{array}{l}\text { Kembali ke halaman } \\
\text { menu utama }\end{array}$ & Berhasil \\
\hline \multicolumn{4}{|c|}{ Halaman Sub Menu Mulai AR } \\
\hline 1 & Pandawa & $\begin{array}{l}\text { Menuju halaman deteksi } \\
\text { marker }\end{array}$ & Berhasil \\
\hline 2 & Punakawan & $\begin{array}{l}\text { Menuju halaman deteksi } \\
\text { marker }\end{array}$ & Berhasil \\
\hline 3 & Back & $\begin{array}{l}\text { Kembali ke halaman } \\
\text { sebelumnya }\end{array}$ & Berhasil \\
\hline 4 & Home & $\begin{array}{l}\text { Kembali ke halaman } \\
\text { menu utama }\end{array}$ & Berhasil \\
\hline \multicolumn{4}{|c|}{ Halaman Sub Menu Sejarah } \\
\hline 1 & Pandawa & $\begin{array}{l}\text { Menuju halaman sejarah } \\
\text { Pandawa }\end{array}$ & Berhasil \\
\hline 2 & Punakawan & $\begin{array}{l}\text { Menuju halaman sejarah } \\
\text { Punakawan }\end{array}$ & Berhasil \\
\hline 3 & Back & $\begin{array}{l}\text { Kembali ke halaman } \\
\text { sebelumnya }\end{array}$ & Berhasil \\
\hline 4 & Home & $\begin{array}{l}\text { Kembali ke halaman } \\
\text { menu utama }\end{array}$ & Berhasil \\
\hline \multicolumn{4}{|c|}{ Halaman Sub Menu Mainkan Tokoh (Deteksi Marker) } \\
\hline 1 & Back & $\begin{array}{l}\text { Kembali ke halaman } \\
\text { sebelumnya }\end{array}$ & Berhasil \\
\hline 2 & Home & $\begin{array}{l}\text { Kembali ke halaman } \\
\text { menu utama }\end{array}$ & Berhasil \\
\hline \multicolumn{4}{|c|}{ Halaman Menu Petunjuk } \\
\hline 1 & Home & $\begin{array}{l}\text { Kembali ke halaman } \\
\text { menu utama }\end{array}$ & Berhasil \\
\hline \multicolumn{4}{|c|}{ Halaman Menu Developer } \\
\hline 1 & Home & $\begin{array}{l}\text { Kembali ke halaman } \\
\text { menu utama }\end{array}$ & Berhasil \\
\hline
\end{tabular}

\subsubsection{Pengujian Marker}

\section{a. Pengujian intensitas cahaya}

Pada pengujian intensitas cahaya sendiri dilakukan dalam dua kondisi, yaitu di dalam ruangan dan diluar ruangan. Untuk pengujian di dalam ruangan dilakukan dengan kondisi intensitas cahaya berkisar 23 lux, 44 lux dan 84 lux. Sedangkan di luar ruangan dengan intensitas cahaya berkisar 291 lux. Dari pengujian tersebut dihasilkan bahwa di dalam ruangan dengan intensitas cahaya 84 lux dan di luar ruangan dengan intensitas cahaya 291 lux deteksi marker lebih cepat dan objek 3D dapat tampil dengan baik.

\section{b. Pengujian Oklusi}

Yang terakhir marker tertutup $75 \%$ hasilnya marker tidak terdeteksi sama sekali. Pengujian oklusi atau pengujian marker yang terhalang sesuatu. Pengujian ini dilakukan untuk mengetahui apakah marker tetap dapat terdeteksi dengan kondisi tidak normal. Pengujian oklusi ini dilakukan dengan cara menutup marker $25 \%$ bagian, $50 \%$ bagian, $65 \%$ bagian, dan $75 \%$ bagian. Dari pengujian tersebut dihasilkan bahwa marker yang tertutup $25 \%$ bagian maka marker tersebut dapat terdeteksi dan objek 3D dapat tampil dengan baik. Kemudian untuk marker tertutup $50 \%$ marker tersebut dapat terdeteksi dan objek 3D tetap dapat tampil dengan baik. Sedangan marker tertutup $65 \%$ marker terdeteksi dan objek dapat ditampilkan, namun objek tidak dapat tampil dengan sempurna.

\section{c. Pengujian Akurasi}

Pengujian akurasi diar Pengujian akurasi diartikan sebagai pengujian pemindaian objek dari jarak tertentu, yaitu pada jarak $15 \mathrm{~cm}, 20$ $\mathrm{cm}, 25 \mathrm{~cm}, 30 \mathrm{~cm}$ antara marker dan kamera. Dari pengujian tersebut dihasilkan bahwa jarak terbaik antara kamera dengan marker yaitu antara jarak $15 \mathrm{~cm}$ dan $20 \mathrm{~cm}$ untuk pendeteksian marker dan tampilnya objek 3D. Kemudian untuk jarak $25 \mathrm{~cm}$ marker dapat terdeteksi dan objek 3D dapat tampil namun tidak sempurna. Sedangkan pada jarak $30 \mathrm{~cm}$ marker tidak terdeteksi sama sekali.

\section{KESIMPULAN DAN SARAN \\ 5.1 Kesimpulan}

Penelitian ini menghasilkan sebuah penerapan Augmented Reality pada Aplikasi "Pandukawan" (Pengenalan Wayang Pandawa dan Punakawan) sebagai media belajar untuk mempermudah peserta didik dan masyarakat 
sekitar Perkumpulan Seni Budaya dan Gedung Cagar Budaya "Sobokartti" dalam mengenal tokoh Pandawa dan Punakawan.

Hasil pengujian pada aplikasi menunjukkan bahwa setiap proses pada aplikasi AR ini berjalan dengan baik dan sesuai dengan rancangan. Hasil pengujian intensitas cahaya (dilakukan dengan intensitas cahaya minimal 23 lux), oklusi (tertutup $25 \%$ bagian, $50 \%$ bagian, $65 \%$ bagian, dan $75 \%$ ), dan akurasi (jarak 15 $\mathrm{cm}, 20 \mathrm{~cm}, 25 \mathrm{~cm}$ dan $30 \mathrm{~cm}$ antara marker dan kamera) menunjukkan bahwa beberapa kondisi dapat mempengaruhi proses pendeteksian marker.

\subsection{Saran}

Berdasarkan penelitian ini, saran untuk penelitian selanjutnya adalah pengembangan aplikasi Augmented Reality "Pandukawan" (Pengenalan Wayang Pandawa dan Punakawan) sebagai media belajar untuk mempermudah peserta didik dan masyarakat sekitar Perkumpulan Seni Budaya dan Gedung Cagar Budaya "Sobokartti" yang lebih sempurna. Pengembangan tersebut bisa meliputi:

a. Pada proses tracking marker dapat menggunakan algoritma lain.

b. Selain itu diharapkan ada pengembang selanjutnya yang mengangkat tokohpewayangan Kurawa tidak hanya tokoh Pandawa dan tokoh Punakawan.

\section{DAFTAR PUSTAKA}

Carmigniani, J. and Furht, B.2011.Augmented Reality: An Overview. In: Furht, B., Ed., Handbook of Augmented Reality, Springer, New York, 3-46.

Pressman, R.S. 2010. Software Engineering: a Practioner's Approach 7th Edition, McGrawHill Higher Education.

Tim Presentasi. 2008. Simbolisme Lakon Dewa Ruci dalam Wayang Kulit Purwa (makalah dipresentasikan pada Mata Kuliah Kebudayan Jawa 25 maret 2008). Surakarta : Tim Penyusun. 